\title{
Anion Induced Synthesis, Structural Characterization and Antibacterial Activity of Zinc(II) Complexes Derived from 5-Bromo-2-((2-(diethylamino)ethylimino)methyl) phenol
}

\author{
Huan-Yu Liu, ${ }^{\star}$ Xiang Gan, Jin-Yan Ding, Zhi-Tao Li and Qiao Chen \\ ${ }^{1}$ School of Chemistry and Chemical Engineering, Guangdong Pharmaceutical University, Zhongshan 528458, P.R. China \\ ${ }^{2}$ Guangdong Cosmetics Engineering and Technology Research Center, Zhongshan 528458, P.R. China \\ ${ }^{3}$ Guangdong Provincial Key Laboratory of Pharmaceutical Bioactive Substances, \\ Guangdong Pharmaceutical University, Guangzhou 510006, P.R. China \\ *Corresponding author: E-mail: liuhuanyu03@163.com
}

Received: 02-01-2021

\begin{abstract}
By changing the anions of zinc salts, three different zinc(II) complexes, $\left[\mathrm{Zn}_{2}(\mathrm{HL})_{2}(\mathrm{NCS})_{4}\right] \cdot 2 \mathrm{CH}_{3} \mathrm{OH}(\mathbf{1}),\left[\mathrm{Zn}_{2} \mathrm{~L}\left(\mu_{2}-\eta^{1}: \eta^{1}-\right.\right.$ $\left.\left.\mathrm{CH}_{3} \mathrm{COO}\right)_{2}(\mathrm{NCS})\right](2)$ and $\left[\mathrm{Zn}(\mathrm{HL}) \mathrm{I}_{2}\right] \cdot \mathrm{CH}_{3} \mathrm{OH}(3)$, where $\mathrm{L}=5$-bromo-2-((2-(diethylamino)ethylimino)methyl)phenolate, $\mathrm{HL}=5$-bromo-2-((2-(diethylammonio)ethylimino)methyl)phenolate, have been synthesized and characterized by IR and UV-Vis spectroscopy, as well as single-crystal X-ray diffraction. X-ray analysis indicates that the $\mathrm{Zn}$ atoms in the complexes are in trigonal bipyramidal, square pyramidal and tetrahedral coordination. The anions of the zinc salts lead to the formation of different structures of the complexes. Antibacterial activity of the complexes against Staphylococcus aureus, Escherichia coli, Klebsielle pneumoniae and Candida albicans strains was studied.
\end{abstract}

Keywords: Schiff base; Zinc complex; Self-assembly; Crystal structure; Antibacterial activity

\section{Introduction}

Schiff base compounds play important role in the pharmaceutical industry as antibacterial, antiradical, antifungal, anticancer and antiviral agents. ${ }^{1}$ Salen type Schiff bases are privileged ligands in coordination chemistry that can form versatile structures of complexes with various metals. ${ }^{2}$ Among the large number of Schiff base complexes, those with zinc atoms have received particular attention due to their remarkable biological activities. ${ }^{3}$ Zinc is the second most abundant trace metal in the human body and can be considered as non-toxic to humans. It is essential for the structures, regulation and catalytic action of over 300 enzymes. ${ }^{4}$ The structures of Schiff base complexes are sensitive. A number of zinc complexes have shown antimicrobial activities, ${ }^{5}$ and therefore zinc complexes deserve further attention in this regard. In this paper, three new zinc(II) complexes, $\left[\mathrm{Zn}_{2}(\mathrm{HL})_{2}(\mathrm{NCS})_{4}\right] \cdot 2 \mathrm{CH}_{3} \mathrm{OH}(\mathbf{1})$, $\left[\mathrm{Zn}_{2} \mathrm{~L}\left(\mu_{2}-\eta^{1}: \eta^{1}-\mathrm{CH}_{3} \mathrm{COO}\right)_{2}(\mathrm{NCS})\right]$ (2) and $\left[\mathrm{Zn}(\mathrm{HL}) \mathrm{I}_{2}\right]$. $\mathrm{CH}_{3} \mathrm{OH}$ (3), where $\mathrm{L}=5$-bromo-2-((2-(diethylamino) ethylimino $)$ methyl $)$ phenolate, $\mathrm{HL}=5$-bromo-2-((2-(diethylammonio)ethylimino)methyl)phenolate, have been synthesized, characterized, and assayed for the antibacterial effects.

\section{Experimental}

\section{1. General Methods and Materials}

Zinc nitrate, zinc acetate, zinc iodide, ammonium thiocyanate, 4-bromosalicylaldehyde and N,N-diethylethane-1,2-diamine were obtained from Sigma-Aldrich. All other reagents were of analytical reagent grade. Elemental analyses $(\mathrm{C}, \mathrm{H}, \mathrm{N})$ were performed with a PE-2400 II apparatus. Infrared spectra were recorded on $\mathrm{KBr}$ pellets with a Nicolet Nexus 670 FT-IR spectrometer in the 400 $4000 \mathrm{~cm}^{-1}$ range. UV-Vis spectra were obtained on a Lambda 900 spectrometer. Molar conductance was measured with a Shanghai DDS-11A conductometer. X-ray dif- 
fraction was carried out on a Bruker SMART 1000 CCD diffractometer.

\section{2. Synthesis of $\left[\mathrm{Zn}_{2}(\mathrm{HL})_{2}(\mathrm{NCS})_{4}\right] \cdot 2 \mathrm{CH}_{3} \mathrm{OH}$} (1)

4-Bromosalicylaldehyde $(1.0 \mathrm{mmol}, 0.20 \mathrm{~g})$ and $\mathrm{N}, \mathrm{N}$-diethylethane-1,2-diamine $(1.0 \mathrm{mmol}, 0.12 \mathrm{~g})$ were dissolved in methanol and refluxed for $10 \mathrm{~min}$. After cooling to room temperature, zinc nitrate hexahydrate $(2.0$ $\mathrm{mmol}, 0.38 \mathrm{~g}$ ) was added to the solution, and stirred for 10 $\mathrm{min}$. Then, ammonium thiocyanate $(2.0 \mathrm{mmol}, 0.15 \mathrm{~g})$ was added and stirred for another $10 \mathrm{~min}$ and filtered. The filtrate was allowed to evaporate slowly for 3 days at room temperature and colorless crystals were obtained. The crystals were isolated by filtration, washed with methanol and dried in air. Yield: $0.23 \mathrm{~g}(45 \%)$. Anal. Calcd. for $\mathrm{C}_{32} \mathrm{H}_{46} \mathrm{Br}_{2} \mathrm{~N}_{8} \mathrm{O}_{4} \mathrm{~S}_{4} \mathrm{Zn}_{2}$ (\%): C, 37.47; H, 4.52; N, 10.93 . Found (\%): C, 37.33; H, 4.63; N, 11.12. IR data (KBr, $v_{\max } /$ $\left.\mathrm{cm}^{-1}\right)$ : $3616(\mathrm{OH}), 3381(\mathrm{NH}), 2095,2070(\mathrm{NCS}), 1634$ $(\mathrm{C}=\mathrm{N}), 1578,1530,1474,1455,1391,1273,1192,1133$, $1085,1023,961,919,857,793,598,583,523,477,455$. UVVis data $\left(\mathrm{MeOH} ; \lambda_{\max }, \mathrm{nm}\right): 227,247,266,322,365$.

\section{3. Synthesis of $\left[\mathrm{Zn}_{2} \mathrm{~L}\left(\boldsymbol{\mu}_{2}-\eta^{1}: \eta^{1}-\right.\right.$ $\left.\left.\mathrm{CH}_{3} \mathrm{COO}\right)_{2}(\mathrm{NCS})\right](2)$}

4-Bromosalicylaldehyde $(1.0 \mathrm{mmol}, 0.20 \mathrm{~g})$ and $\mathrm{N}, \mathrm{N}$-diethylethane-1,2-diamine $(1.0 \mathrm{mmol}, 0.12 \mathrm{~g})$ were dissolved in methanol and refluxed for $10 \mathrm{~min}$. After cool- ing to room temperature, zinc acetate dihydrate $(2.0 \mathrm{mmol}$, $0.22 \mathrm{~g}$ ) was added to the solution, and stirred for $10 \mathrm{~min}$. Then, ammonium thiocyanate $(2.0 \mathrm{mmol}, 0.15 \mathrm{~g})$ was added and stirred for another $10 \mathrm{~min}$ and filtered. The filtrate was allowed to evaporate slowly for 5 days at room temperature and colorless crystals were obtained. The crystals were isolated by filtration, washed with methanol and dried in air. Yield: $0.34 \mathrm{~g}(56 \%)$. Anal. Calcd. for $\mathrm{C}_{18} \mathrm{H}_{24} \mathrm{BrN}_{3} \mathrm{O}_{5} \mathrm{SZn}_{2}$ (\%): C, 35.73; H, 4.00; N, 6.94. Found (\%): C, 35.87; H, 4.12; N, 6.85. IR data $\left(\mathrm{KBr}, v_{\max } / \mathrm{cm}^{-1}\right)$ : 2083 (NCS), $1648(\mathrm{C}=\mathrm{N}), 1592,1538,1477,1443,1394$, $1345,1277,1205,1173,1076,1042,936,910,851,795,736$, $668,617,600,543,460$. UV-Vis data $\left(\mathrm{MeOH} ; \lambda_{\max }, \mathrm{nm}\right)$ : $240,275,343$.

\section{4. Synthesis of $\left[\mathrm{Zn}(\mathrm{HL}) \mathrm{I}_{2}\right] \cdot \mathrm{CH}_{3} \mathrm{OH}(3)$}

4-Bromosalicylaldehyde $(1.0 \mathrm{mmol}, 0.20 \mathrm{~g})$ and $\mathrm{N}, \mathrm{N}$-diethylethane-1,2-diamine $(1.0 \mathrm{mmol}, 0.12 \mathrm{~g})$ were dissolved in methanol and refluxed for $10 \mathrm{~min}$. After cooling to room temperature, zinc iodide $(2.0 \mathrm{mmol}, 0.32 \mathrm{~g})$ was added to the solution, and stirred for $10 \mathrm{~min}$. Then, ammonium thiocyanate $(2.0 \mathrm{mmol}, 0.15 \mathrm{~g})$ was added and stirred for another $10 \mathrm{~min}$ and filtered. The filtrate was allowed to evaporate slowly for 6 days at room temperature and colorless crystals were obtained. The crystals were isolated by filtration, washed with methanol and dried in air. Yield: $0.41 \mathrm{~g}$ (64\%). Anal. Calcd. for $\mathrm{C}_{13} \mathrm{H}_{21} \mathrm{BrI}_{2} \mathrm{~N}_{2} \mathrm{O}_{2} \mathrm{Zn}$ (\%): C, 24.53; H, 3.33; N, 4.40. Found (\%): C, 24.66; H, 3.24; $\mathrm{N}, 4.47$. IR data $\left(\mathrm{KBr}, v_{\max } / \mathrm{cm}^{-1}\right): 3528(\mathrm{OH}), 3286$

Table 1. Crystallographic and refinement data for the complexes

\begin{tabular}{|c|c|c|c|}
\hline & 1 & 2 & 3 \\
\hline Molecular formula & $\mathrm{C}_{32} \mathrm{H}_{46} \mathrm{Br}_{2} \mathrm{~N}_{8} \mathrm{O}_{4} \mathrm{~S}_{4} \mathrm{Zn}_{2}$ & $\mathrm{C}_{18} \mathrm{H}_{24} \mathrm{BrN}_{3} \mathrm{O}_{5} \mathrm{SZn}_{2}$ & $\mathrm{C}_{13} \mathrm{H}_{21} \mathrm{BrI}_{2} \mathrm{~N}_{2} \mathrm{O}_{2} \mathrm{Zn}$ \\
\hline Formula weight & 1025.57 & 605.11 & 636.40 \\
\hline$T, \mathrm{~K}$ & 298(2) & $298(2)$ & 298(2) \\
\hline Crystal system & Monoclinic & Monoclinic & Monoclinic \\
\hline Space group & $P 2_{1} / n$ & $P 2_{1} / c$ & $P 2_{1} / n$ \\
\hline$a, \AA$ & $8.9614(19)$ & $15.6123(13)$ & $8.1733(11)$ \\
\hline$b, \AA$ & $22.7484(17)$ & $8.3289(12)$ & $14.3725(13)$ \\
\hline$c, \AA$ & $10.5794(13)$ & $18.4164(15)$ & $17.1426(13)$ \\
\hline$\beta,{ }^{\circ}$ & $97.195(2)$ & $93.024(1)$ & $92.850(1)$ \\
\hline$V, \AA^{3}$ & $2139.7(5)$ & $2391.4(4)$ & $2011.3(4)$ \\
\hline$Z$ & 2 & 4 & 4 \\
\hline$\rho_{\text {calcd }}, \mathrm{g} \mathrm{cm}^{-3}$ & 1.592 & 1.681 & 2.102 \\
\hline$\mu\left(\mathrm{MoK}_{\alpha}, \mathrm{mm}^{-1}\right)$ & 3.228 & 3.796 & 6.282 \\
\hline$F(000)$ & 1040 & 1216 & 1200 \\
\hline Measured reflections & 11876 & 13619 & 10379 \\
\hline Unique reflections & 3945 & 4451 & 3737 \\
\hline Observed reflections $(I \geq 2 \sigma(I))$ & 2467 & 2659 & 2501 \\
\hline Parameters & 238 & 326 & 198 \\
\hline Restraints & 0 & 90 & 3 \\
\hline Goodness of fit on $F^{2}$ & 0.996 & 1.006 & 0.998 \\
\hline$R_{1}, w R_{2}\left(I \geq 2 \sigma(I)^{*}\right.$ & $0.0628,0.1840$ & $0.0380,0.0909$ & $0.0502,0.1209$ \\
\hline$R_{1}, w R_{2}$ (all data) ${ }^{*}$ & $0.1109,0.2397$ & $0.0802,0.1090$ & $0.0809,0.1392$ \\
\hline
\end{tabular}

${ }^{*} R_{1}=\Sigma|| F_{\mathrm{o}}|-| F_{\mathrm{c}}|| \Sigma\left|F_{\mathrm{o}}\right|, w R_{2}=\left\{\Sigma\left[w\left(F_{\mathrm{o}}{ }^{2}-F_{\mathrm{c}}{ }^{2}\right)^{2}\right] / \Sigma\left[w\left(F_{\mathrm{o}}{ }^{2}\right)^{2}\right]\right\}^{1 / 2}$ 
(NH), $1626(\mathrm{C}=\mathrm{N}), 1580,1515,1462,1429,1401,1287$, $1233,1180,1133,1066,1053,923,870,803,779,683,602$, $570,527,498,462$. UV-Vis data $\left(\mathrm{MeOH} ; \lambda_{\max }, \mathrm{nm}\right): 218$, $245,267,366$.

\section{5. X-ray Crystallography}

The program SAINT was used for integration of the diffraction profiles. ${ }^{6}$ Structures were solved by direct methods using the SHELXS program of the SHELXTL package and refined by full-matrix least-squares methods with SHELXL (semi-empirical absorption corrections were applied using the SADABS program). ${ }^{7}$ The positions of the non-hydrogen atoms were located in difference Fourier syntheses and least-squares refinement cycles, and finally refined anisotropically. The C8-C9-N2-C10-C11C12-C13 moiety of complex 2 is disordered over two sites, with occupancies of $0.52(1)$ and $0.48(1)$. The water hydrogen atoms of complex 3 were located from the electronic density map and refined isotropically, with $\mathrm{O}-\mathrm{H}$ and $\mathrm{H} \cdots \mathrm{H}$ distances restrained to $0.85(1)$ and $1.37(2) \AA$, respectively. The remaining hydrogen atoms of the complexes were

Table 2. Selected bond distances $(\AA)$ and angles $\left(^{\circ}\right)$ for the complexes

\begin{tabular}{|c|c|c|c|}
\hline & & 1 & \\
\hline $\mathrm{Zn} 1-\mathrm{O} 1$ & $1.965(5)$ & $\mathrm{Zn} 1-\mathrm{N} 1$ & $2.123(6)$ \\
\hline $\mathrm{Zn} 1-\mathrm{N} 3$ & $1.971(7)$ & $\mathrm{Zn} 1-\mathrm{N} 4$ & $1.994(7)$ \\
\hline $\mathrm{Zn} 1-\mathrm{O} 1 \mathrm{~A}$ & $2.224(5)$ & & \\
\hline $\mathrm{O} 1-\mathrm{Zn} 1-\mathrm{N} 3$ & $118.5(3)$ & $\mathrm{O} 1-\mathrm{Zn} 1-\mathrm{N} 4$ & $123.9(3)$ \\
\hline N3-Zn1-N4 & $116.1(3)$ & $\mathrm{O} 1-\mathrm{Zn} 1-\mathrm{N} 1$ & $90.1(2)$ \\
\hline N3-Zn1-N1 & $97.0(3)$ & $\mathrm{N} 4-\mathrm{Zn} 1-\mathrm{N} 1$ & $95.2(3)$ \\
\hline $\mathrm{O} 1-\mathrm{Zn} 1-\mathrm{O} 1 \mathrm{~A}$ & $77.4(2)$ & $\mathrm{N} 3-\mathrm{Zn} 1-\mathrm{O} 1 \mathrm{~A}$ & $90.0(2)$ \\
\hline \multirow[t]{2}{*}{$\mathrm{N} 4-\mathrm{Zn} 1-\mathrm{O} 1 \mathrm{~A}$} & $91.0(2)$ & $\mathrm{N} 1-\mathrm{Zn} 1-\mathrm{O} 1 \mathrm{~A}$ & $167.48(19)$ \\
\hline & & 2 & \\
\hline $\mathrm{Zn} 1-\mathrm{O} 1$ & $2.110(3)$ & $\mathrm{Zn} 1-\mathrm{O} 2$ & $1.987(3)$ \\
\hline $\mathrm{Zn} 1-\mathrm{N} 1$ & $1.997(5)$ & $\mathrm{Zn} 1-\mathrm{N} 2$ & $2.220(4)$ \\
\hline $\mathrm{Zn} 2-\mathrm{N} 3$ & $1.926(5)$ & $\mathrm{Zn} 1-\mathrm{O} 4$ & $1.981(4)$ \\
\hline $\mathrm{Zn} 2-\mathrm{O} 1$ & $1.959(3)$ & $\mathrm{Zn} 2-\mathrm{O} 3$ & $1.961(3)$ \\
\hline $\mathrm{Zn} 2-\mathrm{O} 5$ & $1.945(3)$ & & \\
\hline $\mathrm{O} 4-\mathrm{Zn} 1-\mathrm{O} 2$ & $107.45(15)$ & $\mathrm{O} 4-\mathrm{Zn} 1-\mathrm{N} 1$ & $143.47(16)$ \\
\hline $\mathrm{O} 2-\mathrm{Zn} 1-\mathrm{N} 1$ & $109.05(16)$ & $\mathrm{O} 4-\mathrm{Zn} 1-\mathrm{O} 1$ & $90.47(13)$ \\
\hline $\mathrm{O} 2-\mathrm{Zn} 1-\mathrm{O} 1$ & $96.39(13)$ & N1-Zn1-O1 & $86.86(15)$ \\
\hline $\mathrm{O} 4-\mathrm{Zn} 1-\mathrm{N} 2$ & $94.51(16)$ & $\mathrm{O} 2-\mathrm{Zn} 1-\mathrm{N} 2$ & $94.36(15)$ \\
\hline $\mathrm{N} 1-\mathrm{Zn} 1-\mathrm{N} 2$ & $81.48(18)$ & $\mathrm{O} 1-\mathrm{Zn} 1-\mathrm{N} 2$ & $166.22(16)$ \\
\hline N3-Zn2-O5 & $111.59(17)$ & N3-Zn2-O1 & $119.37(16)$ \\
\hline $\mathrm{O} 5-\mathrm{Zn} 2-\mathrm{O} 1$ & $101.44(14)$ & $\mathrm{N} 3-\mathrm{Zn} 2-\mathrm{O} 3$ & $107.47(16)$ \\
\hline \multirow[t]{2}{*}{$\mathrm{O} 5-\mathrm{Zn} 2-\mathrm{O} 3$} & $110.21(14)$ & $\mathrm{O} 1-\mathrm{Zn} 2-\mathrm{O} 3$ & $106.46(13)$ \\
\hline & & 3 & \\
\hline Zn1-I1 & $2.5498(10)$ & $\mathrm{Zn} 1-\mathrm{I} 2$ & $2.5906(10)$ \\
\hline $\mathrm{Zn} 1-\mathrm{O} 1$ & $1.955(5)$ & $\mathrm{Zn} 1-\mathrm{N} 1$ & $2.033(5)$ \\
\hline $\mathrm{O} 1-\mathrm{Zn} 1-\mathrm{N} 1$ & $94.6(2)$ & O1-Zn1-I1 & $111.47(16)$ \\
\hline N1-Zn1-I1 & $115.92(17)$ & $\mathrm{O} 1-\mathrm{Zn} 1-\mathrm{I} 2$ & $111.73(17)$ \\
\hline N1-Zn1-I2 & $106.76(17)$ & I1-Zn1-I2 & $114.61(3)$ \\
\hline
\end{tabular}

Symmetry operation for A: $1-x, 1-y,-z$. placed theoretically onto the specific atoms and refined isotropically as riding atoms. Crystallographic data and experimental details for structural analyses are summarized in Table 1. Selected bond lengths and angles for the complexes are listed in Table 2.

\section{6. Antibacterial Assay}

The complexes and ligands were tested for their in vitro antibacterial activity against Staphylococcus aureus, Escherichia coli, Klebsielle pneumoniae and Candida albicans strains using the paper disc diffusion method (for the qualitative determination) and the serial dilutions in liquid broth method (for determination of MIC). ${ }^{8}$ Suspensions in sterile peptone water from $24 \mathrm{~h}$ cultures of microorganisms were adjusted to $0.5 \mathrm{McF}$ arland. Muller-Hinton Petri dishes of $90 \mathrm{~mm}$ were inoculated using these suspensions. Paper disks (6 mm in diameter) containing $10 \mu \mathrm{L}$ of the substance to be tested (at a concentration of $2048 \mu \mathrm{g} /$ $\mathrm{mL}$ in DMSO) were placed in a circular pattern in each inoculated plate. Incubation of the plates was done at $37^{\circ} \mathrm{C}$ for 18-24 h. Reading of the results was done by measuring the diameters of the inhibition zones generated by the tested substances. Tetracycline and fluconazole were used as a reference substance.

Determination of MIC was done using the serial dilutions in liquid broth method. The materials used were 96-well plates, suspensions of microorganism (0.5 McFarland), Muller-Hinton broth (Merck) and stock solutions of each substance to be tested $(2048 \mu \mathrm{g} / \mathrm{mL}$ in DMSO). The following concentrations of the substances to be tested were obtained in the 96-well plates: 1024, 512, 256, 128, 64, $32,16,8.0,4.0$ and $2.0 \mu \mathrm{g} / \mathrm{mL}$. After incubation at $37^{\circ} \mathrm{C}$ for 18-24 h, the MIC for each tested substance was determined by macroscopic observation of microbial growth. It corresponds to the well with the lowest concentration of the tested substance where microbial growth was clearly inhibited.

\section{Results and Discussion}

\section{1. Synthesis and Characterization}

The Schiff base ligand was prepared by the condensation reaction of 4-bromosalicylaldehyde and $N, N$-diethylethane-1,2-diamine in methanol, which was used to prepare the complexes directly. The three complexes were facile synthesized by reaction of the freshly synthesized Schiff base ligand, ammonium thiocyanate and different zinc salts, viz. zinc nitrate for $\mathbf{1}$, zinc acetate for $\mathbf{2}$, and zinc iodide for 3 (Scheme 1). The anions of the zinc salts lead to the formation of different structures of the complexes. The thiocyanate ligand was incorporated in the preparation of the complexes, and it coordinated to complexes $\mathbf{1}$ and $\mathbf{2}$, while absent in complex $\mathbf{3}$. All the complexes are soluble in methanol, ethanol, acetonitrile, 


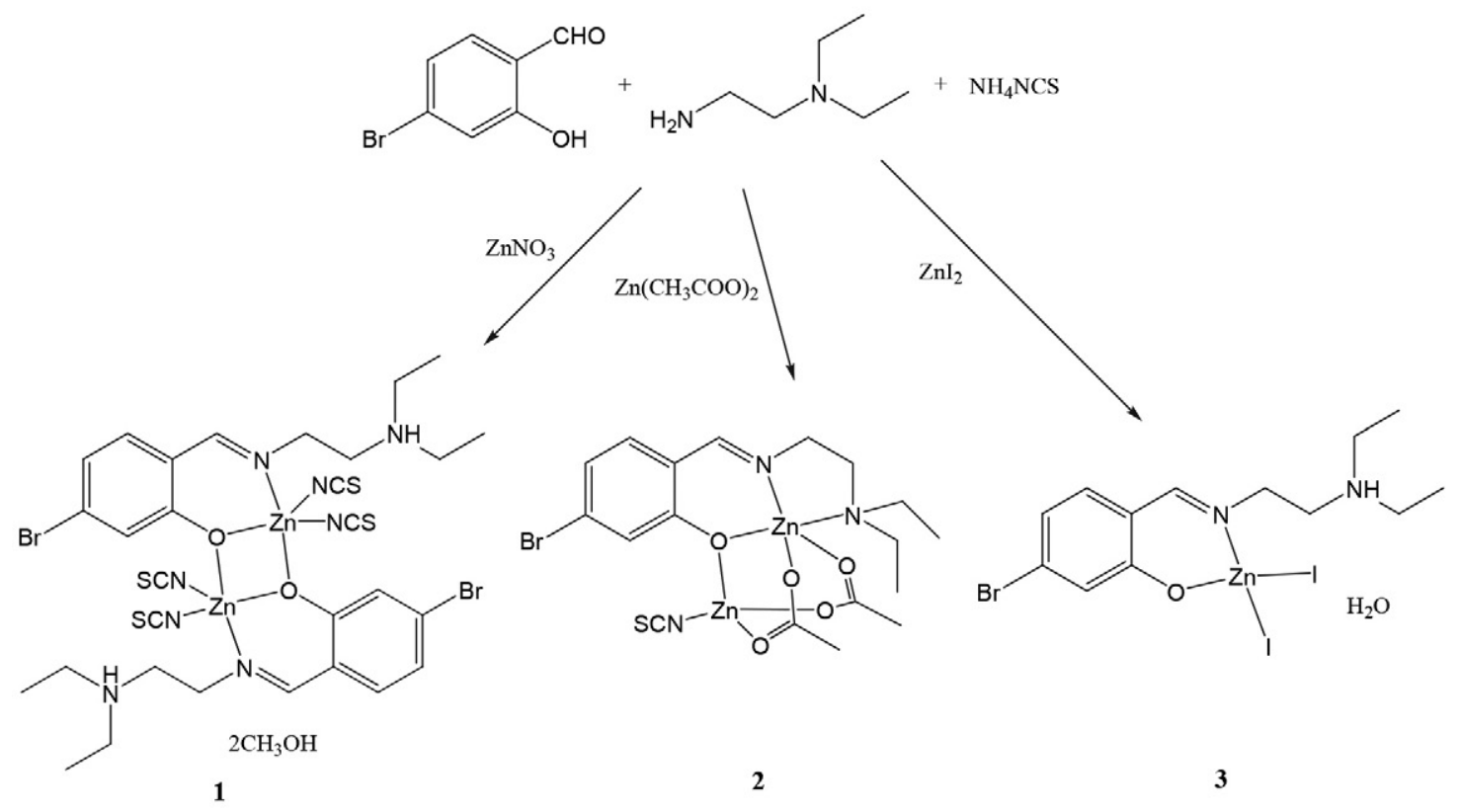

Scheme 1. The synthesis of the complexes

DMF and DMSO, and stable in air at room temperature. Elemental analyses of the complexes are in accordance with the molecular structures proposed by the X-ray analysis. The molar conductivity values in methanol in $20-35 \Omega^{-1} \mathrm{~cm}^{2} \mathrm{~mol}^{-1}$ range indicated that they are non-electrolytes. ${ }^{9}$

\section{2. Structure Description of Complex 1}

The molecular structure of complex $\mathbf{1}$ is shown in Figure 1. The complex bears crystallographic inversion center symmetry. The inversion center is located at the midpoint of the two $\mathrm{Zn}$ atoms, which are bridged by two phenolate $\mathrm{O}$ atoms, and has a separation of 3.273(1) Å. Besides, there are two methanol molecules which are connected to the dinuclear zinc complex molecule via N2$\mathrm{H} 2 \mathrm{~A}$... $\mathrm{O} 2$ hydrogen bonds. Each $\mathrm{Zn}$ atom is coordinated in a trigonal bipyramidal geometry, as evidenced by the $\tau$ value of $0.73 .{ }^{10}$ The basal plane is defined by the phenolate oxygen (O1) and two thiocyanate nitrogen (N3 and N4), and the two axial positions are occupied by the imino nitrogen $(\mathrm{N} 1)$ and the symmetry related phenolate oxygen (O1A). The $\mathrm{Zn}-\mathrm{O} / \mathrm{N}$ bonds are comparable to those observed in similar zinc complexes with Schiff base ligands. ${ }^{11}$ The bond angles in the basal plane vary from 116.1(3) to $123.9(3)^{\circ}$, which are close to the ideal value of $120^{\circ}$. The axial bond N1-Zn1-O1A form an angle of $167.5(2)^{\circ}$, which deviates larger from the ideal value of $180^{\circ}$. The Schiff bases act as bidentate ligands and adopt zwitterionic form, with the amino nitrogen protonated. The four thiocyanate ligands coordinate to the $\mathrm{Zn}$ atoms with terminal coordination mode.

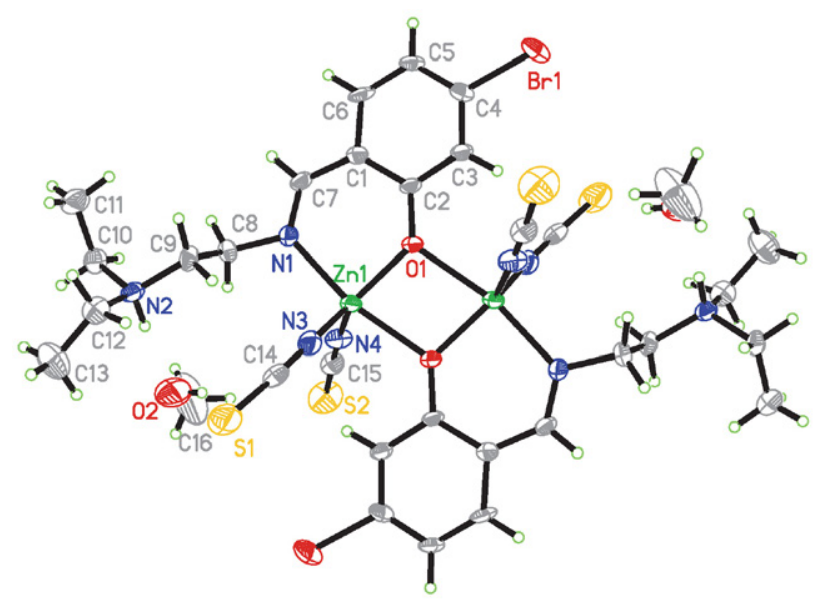

Figure 1. A perspective view of complex 1 with the atom labeling scheme. Thermal ellipsoids are drawn at the $30 \%$ probability level.

\section{3. Structure Description of Complex 2}

The molecular structure of complex 2 is shown in Figure 2. The two $\mathrm{Zn}$ atoms are bridged by one phenolate $\mathrm{O}$ atom, and two acetate ligands, with a distance of 3.131(1) $\AA$. The $\mathrm{Zn} 1$ atom is coordinated in a square pyramidal geometry, as evidenced by the $\tau$ value of $0.38 .{ }^{10}$ The basal plane is defined by the phenolate oxygen $(\mathrm{O} 1)$, imino nitrogen (N1) and amino nitrogen (N2) of the Schiff base ligand, and one acetate oxygen (O4). The apical position is occupied by the acetate oxygen $(\mathrm{O} 2)$. The cis and trans angles in the basal plane are in the ranges of $81.5(2)-94.5(2)^{\circ}$ and $143.5(2)-166.2(2)^{\circ}$, respectively. The bond angles between the apical and basal donor atoms are $94.4(2)-109.0(2)^{\circ}$. Thus, the square pyramidal coordina- 
tion is severely distorted. The $\mathrm{Zn} 1$ atom deviates from the least-squares plane defined by the four basal donor atoms by $0.412(2) \AA$. The $\mathrm{Zn} 2$ atom is coordinated by the phenolate oxygen (O1) of the Schiff base ligand, the thiocyanate nitrogen $(\mathrm{N} 3)$ and two acetate oxygens ( $\mathrm{O} 3$ and $\mathrm{O} 5)$, forming a tetrahedral geometry. The bond angles are in the range of $101.4(2)-119.4(2)^{\circ}$. The $\mathrm{Zn}-\mathrm{O} / \mathrm{N}$ bonds are comparable to those observed in similar zinc complexes with Schiff bases. ${ }^{12}$ The Schiff base acts as a tridentate ligand. The thiocyanate ligand coordinates to the $\mathrm{Zn}$ atom with terminal coordination mode.

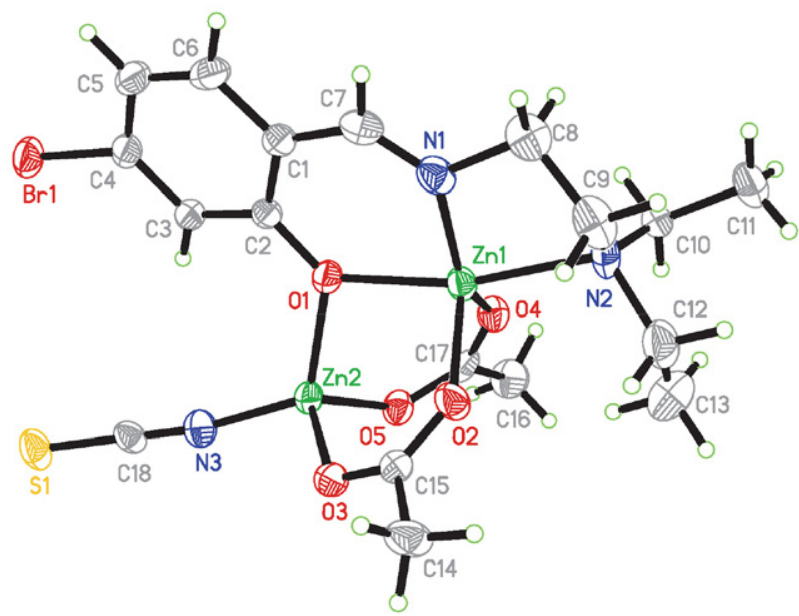

Figure 2. A perspective view of complex $\mathbf{2}$ with the atom labeling scheme. Thermal ellipsoids are drawn at the $30 \%$ probability level. Only the major component of the disordered group is shown.

\section{4. Structure Description of Complex 3}

The molecular structure of complex $\mathbf{3}$ is shown in Figure 3. The water molecule is linked to the zinc complex molecule via $\mathrm{O} 2-\mathrm{H} 2 \mathrm{~A} \cdots \mathrm{O} 1$ hydrogen bond. The $\mathrm{Zn}$ atom is coordinated by the phenolate oxygen (O1) and imino nitrogen (N1) of the Schiff base ligand, and two I atoms (I1 and I2), forming a tetrahedral geometry. The bond angles are in the range of $94.6(2)-115.9(2)^{\circ}$. The $\mathrm{Zn}-\mathrm{O} / \mathrm{N}$ bonds

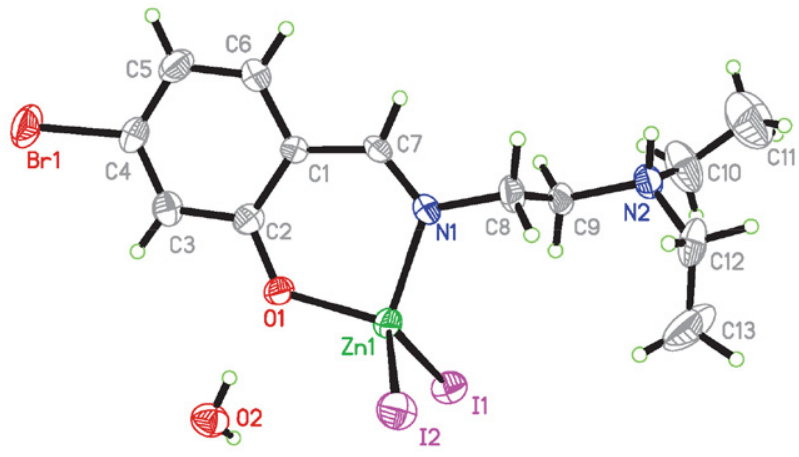

Figure 3. A perspective view of complex $\mathbf{3}$ with the atom labeling scheme. Thermal ellipsoids are drawn at the $30 \%$ probability level. are comparable to those observed in similar zinc complexes with Schiff bases. ${ }^{13}$ The Schiff base acts as a bidentate ligand and adopts zwitterionic form, with the amino nitrogen protonated.

\section{5. Infrared and UV-Vis Spectra}

Infrared spectra provide valuable information regarding the functional group attached to the zinc center. Complex 1 contains non-coordinating methanol molecules, and complex 2 contains non-coordinating water molecule, which are clear from the well-defined bands at $3616 \mathrm{~cm}^{-1}$ for 1 and $3528 \mathrm{~cm}^{-1}$ for 2 . The weak and sharp bands at $3381 \mathrm{~cm}^{-1}$ for 1 and $3286 \mathrm{~cm}^{-1}$ for 3 can be attributed to the $\mathrm{N}-\mathrm{H}$ vibrations. The intense absorptions at $2070-2095 \mathrm{~cm}^{-1}$ for $\mathbf{1}$ and $\mathbf{2}$ arise from the thiocyanate ligands. ${ }^{14}$ The bands at $1270-1290 \mathrm{~cm}^{-1}$ may be assigned to the $\mathrm{Ar}-\mathrm{O}$ stretching vibrations. The typical absorptions at $1626-1648 \mathrm{~cm}^{-1}$ are caused by the vibrations of the azomethine groups of the Schiff base ligands..$^{15}$ The spectrum of complex 2 displays the characteristic bands of acetate ligands at $1592 \mathrm{~cm}^{-1}$ for $v_{\mathrm{as}}\left(\mathrm{CO}_{2}\right)$ and $1394 \mathrm{~cm}^{-1}$ for $v_{\mathrm{s}}\left(\mathrm{CO}_{2}\right) .{ }^{16}$ The bands in the region $400-600 \mathrm{~cm}^{-1}$ may be attributed to $\mathrm{Zn}-\mathrm{O}$ and $\mathrm{Zn}-\mathrm{N}$ vibrations.

The electronic spectra of these complexes were recorded in methanol solution. The bands at $245-275 \mathrm{~nm}$ are attributed to $\pi \rightarrow \pi^{*}$ transitions of the Schiff base ligands. ${ }^{17}$ The charge-transfer bands are observed at $320-370 \mathrm{~nm} .{ }^{18}$

\section{6. Antibacterial Activity}

The three complexes were screened for antibacterial activities. The results are listed in Table 3. Complexes $\mathbf{1}$ and 3 have similar activities against the four bacteria. They show strong activity against Staphylococcus aureus, medium activity against Escherichia coli, and weak activities against Klebsielle pneumonia and Candida albicans. Complex $\mathbf{2}$ has strong activity against Staphylococcus aureus, medium activity against Klebsielle pneumonia, and weak activities against Escherichia coli and Candida albicans. In general, complexes $\mathbf{1}$ and $\mathbf{3}$ have stronger activities against Staphylococcus aureus, Escherichia coli and Candida albicans than complex 2 . While for Klebsielle pneumonia, complex 2 has stronger activity than the other two. All the complexes have better activities on Staphylococcus aureus and Escherichia coli than the zinc complexes with the ligands 4-methoxybenzoic acid (1-pyridin-2-ylmethylidene) hydrazide and benzoic acid (1-pyridin-2-ylethylidene)hydrazide, ${ }^{19}$ the oxovanadium complexes derived from $N^{\prime}$-(3-bromo-2-hydroxybenzylidene)picolinohydrazide and 2-chloro- $N$ '-(2-hydroxy-3-methoxybenzylidene)benzohydrazide,${ }^{20}$ the cobalt, zinc and cadmium complexes derived from 2-hydroxy- $N$ '-(pyridin-2-ylmethylene)benzohydrazide ${ }^{21}$ and the nickel complex with the ligand $N, N^{\prime}$-bis(5-chloro-2-hydroxybenzylidene)-1,3-propanediamine. ${ }^{22}$ Complexes 1 and 3 have better activities on 
Table 3. Antibacterial activity as MIC values $(\mu \mathrm{g} / \mathrm{mL})$

\begin{tabular}{lcccc}
\hline Compound & Staphylococcus aureus & Escherichia coli & Klebsielle pneumoniae & Candida albicans \\
\hline 1 & 0.50 & 4.0 & 16 & 32 \\
2 & 2.0 & 8.0 & 4.0 & 64 \\
3 & 0.50 & 2.0 & 8.0 & 32 \\
Tetracycline & 0.25 & 2.0 & 1.0 & - \\
Fluconazol & - & - & - & 2.0 \\
\hline
\end{tabular}

Staphylococcus aureus and Escherichia coli than the copper complexes with the ligands 2-((2-(dimethylamino) ethylimino)methyl-4,6-difluorophenolate and 2,4-difluoro-6-((3-morpholinopropylimino)methyl)phenolate, ${ }^{23}$ and similar activities with the copper complex derived from 2-hydroxy-5-methylbenzaldehyde oxime. ${ }^{24}$

Notably, complexes $\mathbf{1}$ and $\mathbf{3}$ have similar activity against Staphylococcus aureus, and complex $\mathbf{3}$ has similar activity against Escherichia coli when compared with Tetracycline. The chelation of the Schiff base ligand may reduce the polarity of the metal ion because of partial sharing of its positive charge with the donor group and possible electron delocalization over the whole chelate ring. The coordination may facilitate the ability of a complex to cross the lipid layer of the bacterial cell membrane and in this way may be affected the mechanisms of growth and development of microorganisms. ${ }^{25}$

\section{Conclusion}

Three new zinc complexes derived from the Schiff base ligand 5-bromo-2-((2-(diethylamino)ethylimino) methyl)phenol have been synthesized and characterized. Single crystal structures of the complexes indicate that two of them are dinuclear zinc complexes, and the third one is mononuclear zinc complex. The anions of the zinc salts result in the variation of the final structures. The complexes have interesting antibacterial activities against Staphylococcus aureus, Escherichia coli, Klebsielle pneumoniae and Candida albicans strains.

\section{Supplementary Data}

CCDC 2059026 (1), 2059027 (2) and 2059029 (3) contain the supplementary crystallographic data for this paper. These data can be obtained free of charge via http:// www.ccdc.cam.ac.uk/conts/retrieving.html, or from the Cambridge Crystallographic Data Centre, 12 Union Road, Cambridge CB2 1EZ, UK; fax: (+44) 1223-336-033; or e-mail: deposit@ccdc.cam.ac.uk.

\section{Acknowledgments}

We acknowledge the special funds of Key Disciplines Construction from Guangdong and Zhongshan cooperat- ing, and Guangdong Pharmaceutical University Cosmetics Talent Practice Teaching Base.

\section{References}

1. (a) Y. Chen, P. Li, S. J. Su, M. Chen, J. He, L. W. Liu, M. He, H. Wang, W. Xue, RSC Advances 2019, 9, 23045-23052; DOI:10.1039/C9RA05139B (b) A. Jarrahpour, J. Sheikh, I. El Mounsi, H. Juneja, T. Ben Hadda, Med. Chem. Res. 2013, 22, 1203-1211; DOI:10.1007/s00044-012-0127-6 (c) M. Das, S. Mukherjee, B. Koley, I. Choudhuri, N. Bhattacharyya, P. Roy, B. C. Samanta, M. Barai, T. Maity, New J. Chem. 2020, 44, 18347-18361; DOI:10.1039/D0NJ03844J (d) T. F. F. Magalhaes, C. M. da Silva, L. B. F. dos Santos, D. A. Santos, L. M. Silva, B. B. Fuchs, E. Mylonakis, C. V. B. Martins, M. A. de Resende-Stoianoff, A. de Fatima, Lett. Appl. Microbiol. 2020, 71, 490-497; DOI:10.1111/lam.13356 (e) N. Turan, A. Savci, K. Buldurun, Y. Alan, R. Adiguzel, Lett. Org. Chem. 2016, 13, 343-351; DOI:10.2174/1570178613666160422161855 (f) S. Pasa, M. Tuneg, M. Boga, Pharm. Chem. J. 2019, 53, 302-311; DOI:10.1007/s11094-019-01997-y (g) N. Caliskan, A. Usta, F. S. Beris, N. Baltas, E. Celik, Lett. Org. Chem. 2020, 17, 631638. DOI:10.2174/1570178617666200108111211

2. (a) G. Consiglio, I. P. Oliveri, S. Cacciola, G. Maccarrone, S. Failla, S. Di Bella, Dalton Trans. 2020, 49, 5121-5133; DOI:10.1039/D0DT00494D (b) K. Ghosh, S. Banerjee, S. Chattopadhyay, CrystEngComm 2019, 21, 6026-6037; DOI:10.1039/C9CE00922A (c) D. Majumdar, S. Dey, D. Das, D. K. Singh, S. Das, K. Bankura, D. Mishra, J. Mol. Struct. 2019, 1185, 112-120; DOI:10.1016/j.molstruc.2019.02.092 (d) S. Roy, A. Dey, M. G. B. Drew, P. P. Ray, S. Chattopadhyay, New J. Chem. 2019, 43, 5020-5031; DOI:10.1039/ C8NJ05616A (e) B. Agrahari, S. Layek, R. Ganguly, D. D. Pathak, New J. Chem. 2018, 42, 13754-13762; DOI:10.1039/ C8NJ01718B (f) K. Ghosh, K. Harms, A. Bauza, A. Frontera, S. Chattopadhyay, Dalton Trans. 2018, 47, 331-347. DOI:10.1039/C7DT03929H

3. (a) M. Das, S. Mukherjee, B. Koley, I. Choudhuri, N. Bhattacharyya, P. Roy, B. C. Samanta, M. Barai, T. Maity, New J. Chem. 2020, 44, 18347-18361; DOI:10.1039/D0NJ03844J (b) S. Dasgupta, S. Karim, S. Banerjee, M. Saha, K. D. Saha, D. Das, Dalton Trans. 2020, 49, 1232-1240; DOI:10.1039/ C9DT04636D (c) M. Azam, S. M. Wabaidur, M. J. Alam, A. Trzesowska-Kruszynska, R. Kruszynski, M. Alam, S. I. Al-Resayes, S. Dwivedi, M. R. Khan, M. S. Islam, N. T. M. Lbaqami, Inorg. Chim. Acta 2019, 487, 97-106; DOI:10.1016/j. 
ica.2018.12.009 (d) T. Basak, M. G. B. Drew, S. Chattopadhyay, Inorg. Chem. Commun. 2018, 98, 92-98. DOI:10.1016/j.inoche.2018.10.004

4. E. Ispir, M. Kurtoglu, S. Toroglu, Synth. React. Inorg. Met.Org. Nano-Met. Chem. 2006, 36, 627-631. DOI:10.1080/15533170600910553

5. (a) N. Turan, A. Savci, K. Buldurun, Y. Alan, R. Adiguzel, Lett. Org. Chem. 2016, 13, 343-351; DOI:10.2174/1570178 613666160422161855 (b) S. A. Hosseini-Yazdi, A. Mirzaahmadi, A. A. Khandar, V. Eigner, M. Dusek, M. Mahdavi, S. Soltani, F. Lotfipour, J. White, Polyhedron 2017, 124, 156-165; DOI:10.1016/j.poly.2016.12.004 (c) M. Orojloo, P. Zolgharnein, M. Solimannejad, S. Amani, Inorg. Chim. Acta 2017, 467, 227-237; DOI:10.1016/j.ica.2017.08.016 (d) D. Majumdar, J. K. Biswas, M. Mondal, M. S. S. Babu, R. K. Metre, S. Das, K. Bankura, D. Mishra, J. Mol. Struct. 2018, 1155, 745-757. DOI:10.1016/j.molstruc.2017.11.052

6. Bruker AXS, SAINT Software Reference Manual, Madison, WI, 1998.

7. (a) G. M. Sheldrick, SADABS, Siemens Area Detector Absorption Corrected Software, University of Göttingen: Göttingen, Germany, 1996; (b) G. M. Sheldrick, Acta Crystallogr. 2015, C71, 3-8.

8. T. Rosu, E. Pahontu, S. Pasculescu, R. Georgescu, N. Stanica, A. Curaj, A. Popescu, M. Leabu, Eur. J. Med. Chem. 2010, 45, 1627-1634. DOI:10.1016/j.ejmech.2009.12.015

9. W. J. Geary, Coord. Chem. Rev. 1971, 7, 81-122. DOI:10.1016/S0010-8545(00)80009-0

10. A. W. Addison, T. N. Rao, J. Reedijk, J. van Rijn, G. C. Verschoor, J. Chem. Soc. Dalton Trans. 1984, 7, 1349-1356. DOI:10.1039/DT9840001349

11. (a) A. A. Hoser, W. Schilf, A. S. Chelmieniecka, B. Kolodziej, B. Kamienski, E. Grech, K. Wozniak, Polyhedron 2012, 31, 241-248; DOI:10.1016/j.poly.2011.09.020 (b) H. Adams, L. R. Cummings, D. E. Fenton, P. E. McHugh, Inorg. Chem. Com- mun. 2003, 6, 19-22. DOI:10.1016/S1387-7003(02)00676-7

12. (a) P. Maiti, A. Khan, T. Chattopadhyay, S. Das, K. Manna, D. Bose, S. Dey, E. Zangrando, D. Das, J. Coord. Chem. 2011, 64, 3817-3831; DOI:10.1080/00958972.2011.631534 (b) J. Reglinski, S. Morris, D. E. Stevenson, Polyhedron 2002, 21, 2175-2182. DOI:10.1016/S0277-5387(02)01172-5

13. C. Arici, M. Aksu, Anal. Sci. 2002, 18, 727-728. DOI:10.2116/analsci.18.727

14. S. Basak, S. Sen, S. Banerjee, S. Mitra, G. Rosair, M. T. G. Rodriguez, Polyhedron 2007, 26, 5104-5112. DOI:10.1016/j.poly.2007.07.025

15. A. Jayamani, M. Sethupathi, S. O. Ojwach, N. Sengottuvelan, Inorg. Chem. Commun. 2017, 84, 144-149. DOI:10.1016/j.inoche.2017.08.013

16. B.-H. Ye, X.-Y. Li, I. D. Williams, X.-M. Chen, Inorg. Chem. 2002, 41, 6426-6431. DOI:10.1021/ic025806+

17. L. Pogany, J. Moncol, M. Gal, I. Salitros, R. Boca, Inorg. Chim. Acta 2017, 462, 23-29. DOI:10.1016/j.ica.2017.03.001

18. B. Sarkar, M. G. B. Drew, M. Estrader, C. Diaz, A. Ghosh, Polyhedron 2008, 27, 2625-2633. DOI:10.1016/j.poly.2008.05.004

19. Y.-L. Sang, X.-S. Lin, W.-D. Sun, Acta Chim. Slov. 2020, 67, 581-585. DOI:10.17344/acsi.2019.5595

20. H.-Y. Qian, Acta Chim. Slov. 2019, 66, 995-1001. DOI:10.4149/neo_2019_190112N36

21. L.-H. Wang, X.-Y. Qiu, S.-J. Liu, Acta Chim. Slov. 2019, 66, 675-680. DOI:10.17344/acsi.2019.5117

22. C.-L. Zhang, X.-Y. Qiu, S.-J. Liu, Acta Chim. Slov. 2019, 66, 484-489. DOI:10.17344/acsi.2019.5019

23. S.-F. Yu, X.-Y. Qiu, S.-J. Liu, Acta Chim. Slov. 2020, 67, 13011308. DOI:10.17344/acsi.2020.6321

24. Y.-L. Sang, X.-S. Liu, Acta Chim. Slov. 2019, 66, 168-172.

25. M. Tumer, D. Ekinci, F. Tumer, A. Bulut, Spectrochim. Acta A Mol. Biomol. Spectrosc. 2007, 67, 916-929.

DOI:10.1016/j.saa.2006.09.009

\section{Povzetek}

Sintetizirali smo tri različne cinkove(II) komplekse $\mathrm{z}$ uporabo različnih cinkovih soli: $\left[\mathrm{Zn}_{2}(\mathrm{HL})_{2}(\mathrm{NCS})_{4}\right] \cdot 2 \mathrm{CH}_{3} \mathrm{OH}(\mathbf{1})$, $\left[\mathrm{Zn}_{2} \mathrm{~L}\left(\mu_{2}-\eta^{1}: \eta^{1}-\mathrm{CH}_{3} \mathrm{COO}\right)_{2}(\mathrm{NCS})\right](2)$ in $\left[\mathrm{Zn}(\mathrm{HL}) \mathrm{I}_{2}\right] \cdot \mathrm{CH}_{3} \mathrm{OH}$ (3), kjer je $\mathrm{L}=$ 5-bromo-2-((2-(dietilamino)etilimino) metil)fenolat, $\mathrm{HL}=5$-bromo-2-((2-(dietilammonio)etilimino)metil)fenolat, ter jih okarakterizirali z IR in UV-Vis spektroskopijo kakor tudi z monokristalno rentgensko difrakcijo. Rentgenska strukturna analiza je razkrila, da imajo cinkovi atomi trigonalno bipiramidalno, kvadratno piramidalno in tetraedrično koordinacijo. Anioni v cinkovih soleh vodijo do nastanka različnih struktur. Določili smo tudi antibakterijsko aktivnost spojin na Staphylococcus aureus, Escherichia coli, Klebsielle pneumoniae in Candida albicans.

Except when otherwise noted, articles in this journal are published under the terms and conditions of the Creative Commons Attribution 4.0 International License 